\title{
The ideal response of a Gulf of Mexico estuary plume to wind forcing: Its connection with salt flux and a Lagrangian view
}

\author{
Meng Xia, ${ }^{1,2}$ Lian Xie, ${ }^{3}$ Leonard J. Pietrafesa, ${ }^{3,4}$ and Michael M. Whitney ${ }^{5}$ \\ Received 28 September 2010; revised 16 May 2011; accepted 1 June 2011; published 27 August 2011.
}

[1] The plume structure of Perdido Bay Estuary (PBE), a typical bay on the Florida-Alabama coast along the Gulf of Mexico, was simulated using an existing calibrated model. To better understand plume dynamics in the PBE and similar bay systems, idealized sensitivity experiments were conducted to examine the influence of wind stress on the 3-D plume signature: the results indicate that wind speed and direction significantly influence plume orientation, area, width, length, and depth. The plume size was reduced under the effect of wind and increased wind forcing. Among wind-forced cases, the plume is largest for northerly (offshore) winds and smallest for southerly (onshore) winds. Bay-shelf salt flux and water flux were also investigated, since they are important for the formation of a 3-D plume structure. Model simulations show that water outflow to the coastal ocean is strongest under northerly winds and can be stopped by southerly winds. For moderately strong winds, the outflow and plume size are larger for easterly downwelling-favorable winds than for westerly upwelling-favorable winds; the opposite is true for outflow and plume size for these two wind directions under stronger winds. For all wind directions, the ratio of salt flux and water flux at the bay mouth increases with wind speed. This ratio trend is consistent with higher outflow salinities, and this decreased buoyancy signature, along with more energetic vertical mixing, reduces plume size. A detailed understanding of this water and salt flux is essential to the plume dynamics studied here and for other plumes. Additional particle transport analysis using variable wind forcing was conducted to determine the influence of the plume on particle movement. The results showed a consistency between the surface plume, salt flux, and particle transport and illustrate the strong effects that winds have on particle fate and dispersion.

Citation: Xia, M., L. Xie, L. J. Pietrafesa, and M. M. Whitney (2011), The ideal response of a Gulf of Mexico estuary plume to wind forcing: Its connection with salt flux and a Lagrangian view, J. Geophys. Res., 116, C08035, doi:10.1029/2010JC006689.

\section{Introduction}

[2] River-derived freshwater discharging from an estuary into an adjacent continental shelf forms an estuary plume, which is a common feature in coastal ocean areas. Satellite imagery, such as sea surface temperature and visible-band data along with field observations have provided strong evidence of the presence of estuary plumes along the coasts [Hickey et al., 1998; García Berdeal et al., 2002; Fong and

\footnotetext{
${ }^{1}$ NOAA Living Marine Resources Cooperative Science Center, Department of Natural Sciences, University of Maryland Eastern Shore, Princess Anne, Maryland, USA.

${ }^{2}$ Cooperative Institute for Limnology and Ecosystems Research, NOAA, University of Michigan, Ann Arbor, Michigan, USA.

${ }^{3}$ Department of Marine, Earth, and Atmospheric Sciences, North Carolina State University, Raleigh, North Carolina, USA.

${ }^{4}$ Also at Center for Marine and Wetland Studies, Coastal Carolina University, Conway, South Carolina, USA.

${ }^{5}$ Department of Marine Sciences, University of Connecticut, Groton, Connecticut, USA.

Copyright 2011 by the American Geophysical Union. 0148-0227/11/2010JC006689
}

Geyer, 2002]. Estuary plumes and their corresponding water exchange can alter salinity and change other water properties such as temperature, nutrients, and phytoplankton populations; a plume's low salinity water, as well as the associated fluxes of salt can affect the regional water quality and the composition of local ecosystems. Relatively fresh, low salinity surface plumes have been found to have a strong relationship with bottom hypoxia along the Louisiana Coast [Wiseman et al., 1997].

[3] Previous plume modeling studies have provided a solid foundation for understanding estuary plume dynamics [Beardsley et al., 1985; Chao and Boicourt, 1986; Chao, 1988; Fong and Geyer, 2002; Garvine, 1987, 1999, 2001; Hickey et al., 1998; Li et al., 2008; Marques et al. 2009; O'Donnell, 1990; Takano, 1955; Whitney and Garvine, 2006; Xia et al., 2007; Zhang et al., 1987], but limitations still exist. Few studies have linked plume dynamics with water exchange and salt flux studies, particularly at the mouth. However, studying water exchange and salt flux through the mouth is crucial for understanding plume formation and the dynamical phenomena below the surface layer plume. Also, less research has been 
done to study particle transport within plume structures [Banas et al., 2009; Whitney and Garvine, 2006]. The dynamical relationship among estuary plume structure, water exchange, salt fluxes, and particle transport remains poorly understood. Only a few of the studies have related wind forcing to the water exchange [Geyer, 1997; Valle-Levinson and Blanco, 2004]. Previous studies have shown that wind is an important factor in plume formation due to wind-induced vertical mixing and its horizontal dispersion [Chao and Boicourt, 1986; Hickey et al., 1998; Marques et al. 2009; Whitney and Garvine, 2006; Xia et al., 2007]. For each estuary, it is important to determine the sensitivity of water exchange and plume structure to winds.

[4] Many bay systems interact with the coastal ocean through a narrow inlet; these systems have interesting phenomena that differ from large estuaries with wide mouths. Using satellite imagery, Stumpf et al. [1993] and Li et al. [2008] have shown that a series of enclosed bays in the Gulf of Mexico (hereinafter referred to as Gulf), such as Mobile Bay and Pontchartrain Bay, also have visually obvious estuary plumes. Wind forcing can be particularly important for the Gulf estuary systems [Stumpf et al., 1993; $\mathrm{Li}$ et al., 2008]. However, few numerical studies have focused on plume modeling for these Gulf bay systems. There has been no discussion of the salt flux and particle transport in the Gulf estuary plume and similar regimes. These issues motivate us to understand the effects of local winds on the formation of the Gulf estuary plumes and water exchange dynamics.

[5] Three plume dynamics related questions need be answered: (1) What happens to estuary water when it encounters the relatively low tidal energy in the Gulf, under the effects of wind forcing? (2) How does the plume structure relate to the water exchange and salt flux with regard to changing winds? (3) Does wind play an important role in plume particle transport? In this paper we attempt to answer these questions by examining the influence of wind forcing on three dimensional plume structure using an existing calibrated estuarine and coastal ocean model [Xia et al., 2011]. As a first step, sensitivity experiments were conducted to understand the effect of wind on the variation of the plume signature because river inflow, tidal forcing, and wind all contribute to the plume dynamics. Particle transport, water exchange, and salt flux variations in the Gulf are also explored by selecting a representative bay, Perdido Bay. In section 2 , the numerical model as well as model settings are briefly described, and the implications of the plume dynamics modeling results are discussed in section 3 . Water and salt fluxes are discussed in section 4 , and in section 5 particle transport is depicted. Conclusions are presented in section 6.

\section{Study Area and Model Description}

\subsection{Introduction to Perdido Bay}

[6] A representative example of the Gulf bay system is the Perdido Bay Estuary (PBE), an estuarine system located on the Alabama-Florida border (Figure 1). It is relatively shallow, with an average depth of $2.6 \mathrm{~m}$ that increases gradually from the Perdido River mouth and the upper bay to the Gulf. The Perdido River provides more than $70 \%$ of freshwater input into the estuary. Its river discharge has a mean value of $21 \mathrm{~m}^{3}$ per second (cms) recorded at the U.S. Geological Survey (USGS) station at Barrineau Park, Florida. The bay is characterized by saltwater sounds and marshes and is separated from the Gulf by Perdido Key. There are two intercoastal waterways connecting the bay on the east to "Big Lagoon" and on the west to "Bon Secour Bay." Water exchange directly between the bay and the Gulf occurs through a narrow inlet, Perdido Pass. The width of the narrow inlet ranges from 200 to $500 \mathrm{~m}$, and its depth is around $5 \mathrm{~m}$. The diurnal tidal range is $0.2 \mathrm{~m}$. The Kelvin number (comparing the inlet width to the internal deformation radius) is on the order of 0.1, so its plume can be termed as a small-scale discharge plume based on the definition of Garvine [1995].

\subsection{Hydrodynamic Model and Numerical Settings}

[7] In this study, the Environmental Fluid Dynamics Code (EFDC), a general purpose three-dimensional hydrodynamic model [Hamrick, 1992] is applied in the PBE system. In its inherent physics and in many aspects of the computational scheme, the EFDC resembles the widely used BlumbergMellor model [Blumberg and Mellor, 1987]. The model has sigma coordinates [Blumberg and Mellor, 1987] that can refine the vertical resolution in the layers of interest for the study of near-surface plume formation processes. It also employs orthogonal curvilinear coordinates, allowing grid sizes to vary and fit the estuary coastline. A second corrective step of the scheme for tracer transport referred to as Smolar-2 [Smolarkiewicz, 1983] was also included in the model, which works robustly for long-term mass transport modeling in estuaries and coastal regions [García Berdeal et al., 2002] and clearly outperformed other schemes with this model in our own tests prior to this study. The model embedded a 2.5 order turbulence closure submodel [Mellor and Yamada, 1982; Galperin et al., 1988] with a background viscosity level in which vertical diffusion coefficients are proportional to the turbulent kinetic energy.

[8] In this paper, the simulation domain (Figure 2a) extends from the north at Perdido River, through the Perdido Bay, to the adjacent continental shelf $16 \mathrm{~km}$ from the bay mouth in each direction. A total of 4,372 grid cells exist in the study domain, with grid size varying from $100 \mathrm{~m}$ to $1 \mathrm{~km}$ (Figure 2a) and 11 uniform spacing vertical sigma layers. The highest horizontal resolution is required near the bay mouth and within the nearshore region, the primary plume and coastal current region. Bottom roughness is parameterized with a height of $2 \mathrm{~cm}$; quadratic resistance formulation was applied at the bed to calculate near bed velocity stress components. For the advection scheme, Smolar-2 was used in the simulation. Horizontal turbulent closure is accomplished with the widely used Smagorinsky diffusion formula [Smagorinsky, 1963]. The empirical coefficient is set to 0.1 , the same value that was used in other studies [Garvine, 1999; Kourafalou et al., 1996a, 1996b; Whitney and Garvine, 2006]. Bathymetry was derived from the data provided by the United States Army Corps of Engineers and NOAA's National Geophysical Data Center Coastal Relief Model Volume 02 (www.ngdc.noaa.gov). The model setup has also been discussed in detail by Xia et al. [2011]. The time step was set to $5 \mathrm{~s}$ for all experiments in this study.

\subsection{Boundary Setting, Initial Conditions, and External Forcing}

[9] The calibrated PBE model [Xia et al., 2011] showed that the simulated salinity and measured data are in close 


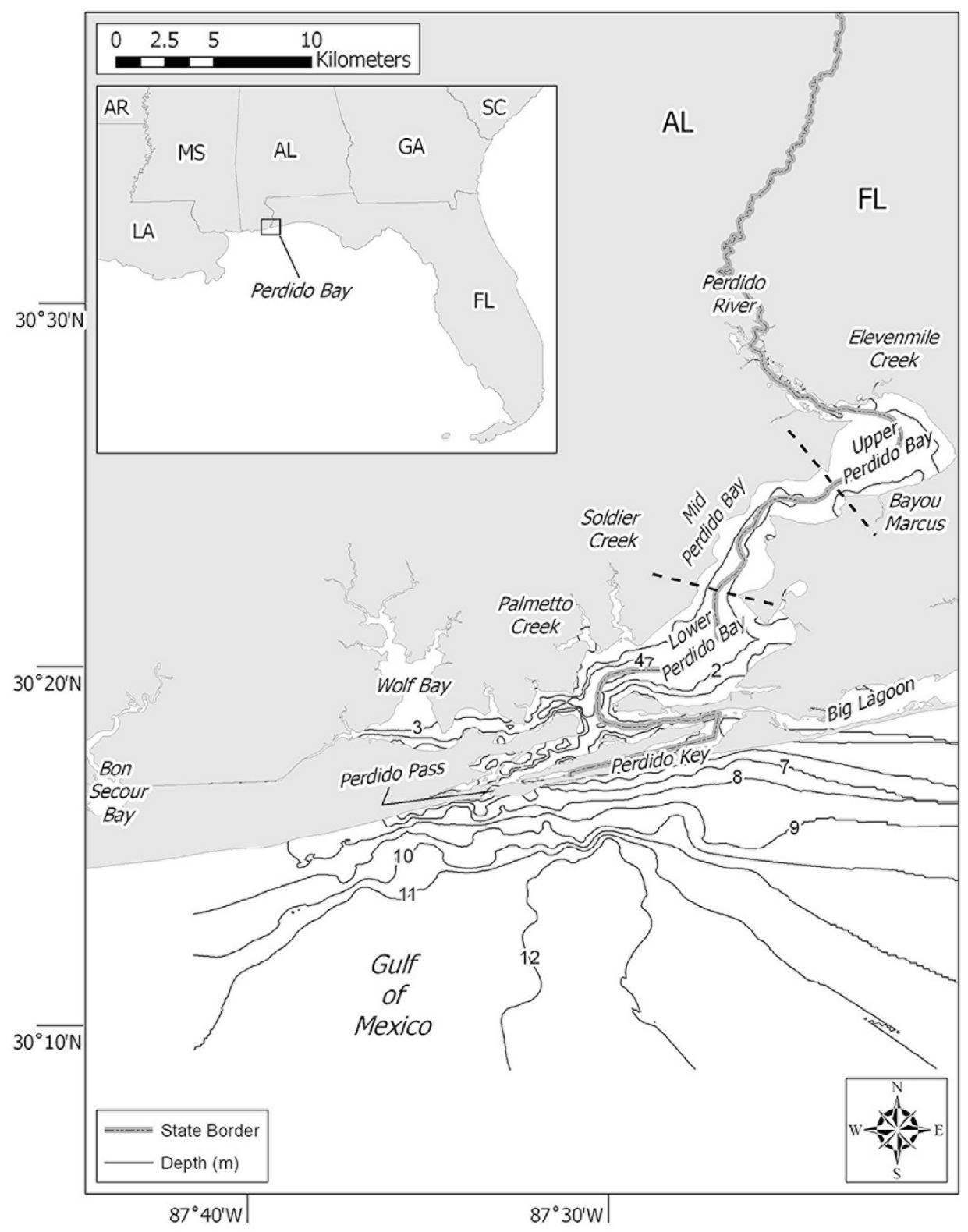

Figure 1. Description of Perdido Bay.

agreement. A solid reproduction of the Perdido Bay threedimensional (3-D) salinity distribution is important since this provides source conditions for correctly understanding the coastal current and bay mouth plume dynamics. The primary forcing agents for plume study are river discharge and winds; these same forcings were used by Whitney and Garvine [2006] in their Delaware Bay buoyancy outflow studies. The simulations are forced with the tide/water level data from NOAA Coastal Ocean Service: the difference in height between mean high water and mean low water is around $0.2 \mathrm{~m}$. Whitney and Garvine [2006] also showed that tidal mixing plays a crucial role for the physical transport within the estuary and adjacent to the mouth. For the open boundary water level along the Gulf, we used the measured tides from the Dauphin Island NOAA National Ocean Services (NOS) tide gage. Additionally, the Intracoastal Water- way was configured with tidal boundary conditions and tidal signals based on the Pensacola NOS tide gage for the eastern channel, and the Dauphin Island NOS tide gage for the western channel.

[10] The Perdido River and Eleven Mile Creek are the major streams of the Perdido River watershed, and their inflow contributes to the estuarine circulation system. The upper model boundary is about $20 \mathrm{~km}$ downstream from the USGS station, and the river discharge is estimated to be around $60 \mathrm{cms}$ at upper model boundary (Perdido River mouth) based on a watershed model calculation from a Florida Department of Environmental Protection unpublished report. For this study, the value of the ideal steady freshwater input was set to $100 \mathrm{cms}$ for the Perdido River and $20 \mathrm{cms}$ for Eleven Mile Creek. River discharge is imposed as a vertically uniform inflow of 0.0 psu water at the upstream 

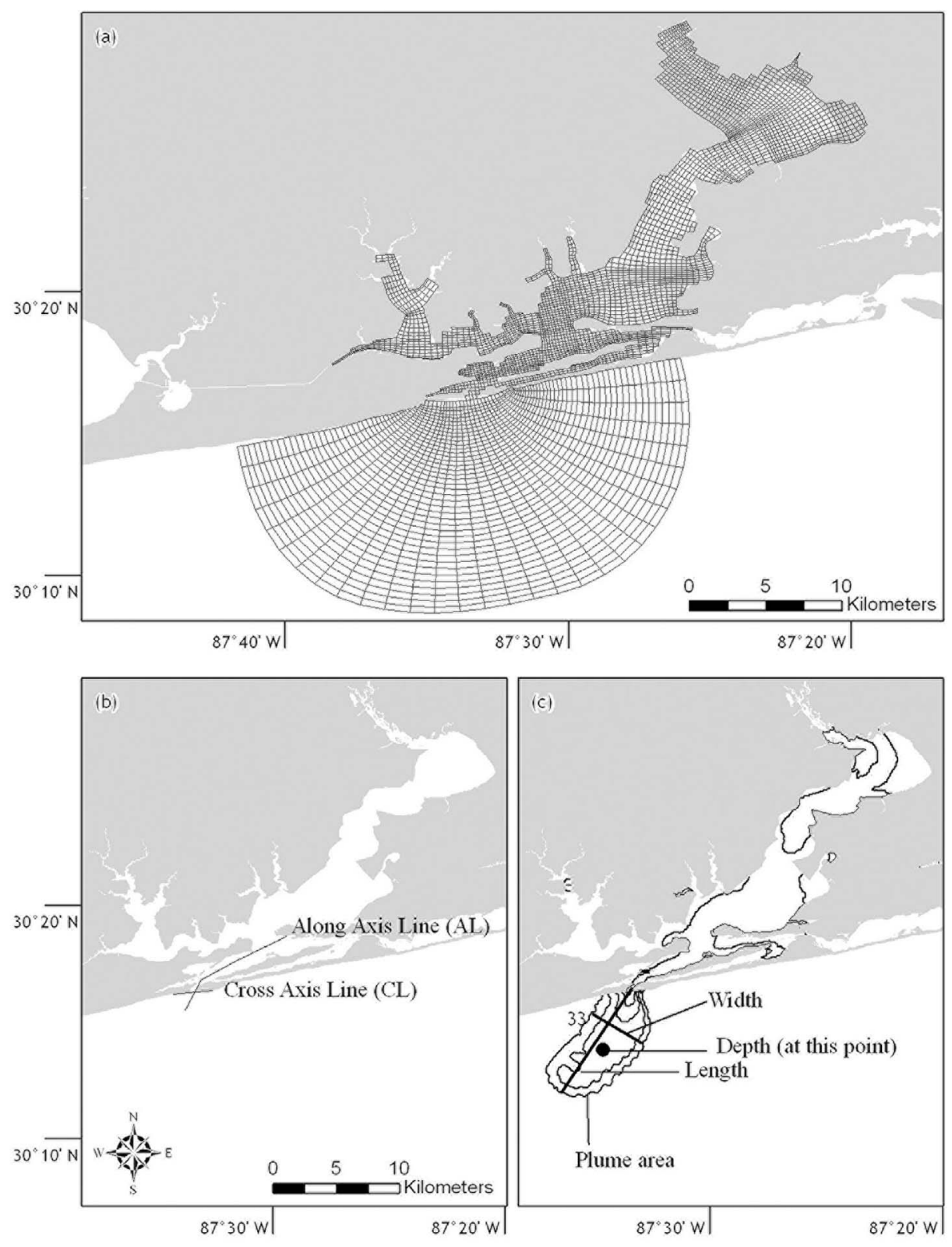

Figure 2. (a) The high horizontal resolution model grid with 4372 cells and (b) the location of vertical profile plot for along-axis line (AL) and cross-axis line (CL). (c) Description of plume signature.

boundary for each river. Open boundary salinity on the shelf is specified as a constant $35.5 \mathrm{psu}$.

[11] Momentum flux is imparted by the wind forcing at the free surface. Ideal spatially uniform wind forcing was set to force the model (Table 1); including northerly, easterly, southerly, and westerly winds with speeds of 3 to $15 \mathrm{~m} / \mathrm{s}$ that are typical for the area. Based on the plume simulation of Li et al. [2008] in their application to a Gulf estuary, all simulations are run for an 8 day period after initialization. A run without wind forcing is used as a benchmark case. The focus here is on the assessment of the response of the PBE system, including the plume, to ideal winds that tend to dominate the synoptic and mesoscale wind field variability. Momentum fluxes have also been balanced by the bottom stress at the bottom boundary.
[12] Salt fluxes are set to zero at the surface, bottom, and land boundaries. Open boundary salinity on the shelf is specified as a constant $35.5 \mathrm{psu}$. The salinity at the east and west intercoastal waterway was based on observation data from the Livingston database (R. J. Livingston, Perdido Bay Analysis: 1988-1998, unpublished report, Florida Department of Environmental Regulation, 2010). Initial estuary salinities were based on observed values from the Livingston database (Livingston, unpublished report, 2010). There is no ambient shelf circulation included in this study, and the density depends solely on salinity, since temperature variations are weak throughout the shallow PBE region. This is consistent with previous studies [e.g., Garvine, 1999; Zhang et al., 1987]. 
Table 1. Model Experiments

\begin{tabular}{llllllll}
\hline & & $\begin{array}{c}\text { River } \\
\text { Discharge }\end{array}$ & $\begin{array}{c}\text { Wind } \\
\text { Direction }\end{array}$ & $\begin{array}{c}\text { Wind } \\
\text { Speed }\end{array}$ & Plume & Flux & Particle \\
\hline Run 0 & No_flow & 0 & no wind & 0 & & yes & \\
Run 1 & No_wind & $100+20$ & no wind & 0 & yes & yes & yes \\
Run 2 & N3 & $100+20$ & northerly & 3 & yes & yes & \\
Run 3 & N5 & $100+20$ & northerly & 5 & yes & yes & yes \\
Run 4 & N7 & $100+20$ & northerly & 7 & yes & yes & \\
Run 5 & N10 & $100+20$ & northerly & 10 & yes & yes & \\
Run 6 & N15 & $100+20$ & northerly & 15 & yes & yes & \\
Run 7 & E3 & $100+20$ & easterly & 3 & yes & yes & \\
Run 8 & E5 & $100+20$ & easterly & 5 & yes & yes & yes \\
Run 9 & E7 & $100+20$ & easterly & 7 & yes & yes & \\
Run 10 & E10 & $100+20$ & easterly & 10 & yes & yes & \\
Run 11 & E15 & $100+20$ & easterly & 15 & yes & yes & \\
Run 12 & S3 & $100+20$ & southerly & 3 & yes & yes & \\
Run 13 & S5 & $100+20$ & southerly & 5 & yes & yes & yes \\
Run 14 & S7 & $100+20$ & southerly & 7 & yes & yes & \\
Run 15 & S10 & $100+20$ & southerly & 10 & yes & yes & \\
Run 16 & S15 & $100+20$ & southerly & 15 & yes & yes & \\
Run 17 & W3 & $100+20$ & westerly & 3 & yes & yes & \\
Run 18 & W5 & $100+20$ & westerly & 5 & yes & yes & yes \\
Run 19 & W7 & $100+20$ & westerly & 7 & yes & yes & yes \\
Run 20 & W10 & $100+20$ & westerly & 10 & yes & yes & yes \\
Run 21 & W15 & $100+20$ & westerly & 15 & yes & yes & yes \\
\hline
\end{tabular}

\subsection{Plume Signature Calculation}

[13] The numerical simulation of plume results were integrated with a Geographic Information System to measure its signature (Figure 2c): the plume area is defined as the area within the 33 psu contour line based on the near surface salinity value; the length is calculated from the bay mouth to the farthest plume point; the width is measured by the across-plume length at the middle part of the plume; the depth of plume is defined by the salinity depth (using $33 \mathrm{psu}$ contour line) at the center of the surface plume.

\subsection{Volume Exchange and Salt Flux Calculations}

[14] At the same time, water exchanges, salt fluxes, and particle transport were also calculated to evaluate the importance of wind forcing on those aspects of the system (Table 1). The average water and salt fluxes are defined as follows:

$$
\begin{aligned}
& \text { Water Flux }=\int_{t_{1}}^{t_{2}} \int_{-h}^{\eta} \int_{x_{1}}^{x_{2}} v d x d h d t / \int_{t_{1}}^{t_{2}} d t \\
& \text { Salt Flux }=\int_{t_{1}}^{t_{2}} \int_{-h}^{\eta} \int_{x_{1}}^{x_{2}} S \bullet v d x d h d t / \int_{t_{1}}^{t_{2}} d t
\end{aligned}
$$

where $\mathrm{v}$ is the cross-inlet velocity perpendicular to the inlet direction, $\mathrm{h}$ is the total water depth, $\eta$ is the water level, $\mathrm{S}$ is the salinity concentration, $\mathrm{dx}$ is the grid width across the inlet or $\mathrm{x}$ direction, $d h$ is the grid depth along the $\mathrm{z}$ direction, $x_{1}$ and $x_{2}$ are the left side and right side locations of the inlet, respectively, $t_{1}$ and $t_{2}$ are the model initialization time and end time (8 days later), $d t$ is the time step.

\subsection{Particle Tracking Method and Its Experiments Designation}

[15] The Lagrangian Particles Tracking (LPT) is integrated with the $3-\mathrm{D}$ velocity field inside the hydrodynamics model. The LPT submodel has been implemented with the options that particles are free to move in full 3-D with a random walk component. A fourth-order Runge Kutta scheme was used for the integration, with the same time step as in the hydrodynamics model with an hourly output. In addition to advection in all three dimensions, particles were subject to vertical diffusion, using the "random displacement" scheme described by Dunsbergen and Stalling [1993]. This scheme adds a random vertical velocity, scaled by the local vertical diffusivity within the hydrodynamic model, to the advective velocity at every time step, and also includes a correction based on the local diffusivity gradient.

[16] Particles are tracked in eight representative modeling scenarios considered in this study (Table 1). Particle experiments tracked transport for 8 days or the plume simulation duration. Like the experiments of Naudin et al. [1997] in their case studies of the Rhone Estuary plume, particles were launched in the inlet between the bay and the coastal ocean. For the purpose of transport within the plume and the underlying marine water, a total of 30 particles were released to follow the vertical variation between 11 vertical layers and the horizontal orientation in either the west or east part of the bay, and the coastal ocean. In the results that follow, these experiments focus on plume-related particle transport. The particle results for different wind directions and speeds will be compared in order to quantify the effect of wind forcing.

\section{Sensitivity Experiments Measuring Plume Dynamics Under a Variety of Wind Forcing}

\subsection{Plume Structure Without Winds}

[17] As a benchmark run, the plume structure is first simulated without wind, a constant river discharge value, and realistic tidal forcing. The results indicate that the PBE plume forms a bulge at the Perdido Bay mouth (Figure 3a), consistent with previous studies in other estuaries [Chao, 1988; Xia et al., 2007; Zhang et al., 1987]. Contrary to these plume simulations, the PBE plume does not show a narrow coastal current stretching along coast on the downshelf (west) side. Instead the plume spreads offshore and along coast in both directions with only a slight downshelf (western) bias. The lack of a well-defined narrow coastal current likely is due to the narrow inlet (relative to the internal deformation radius) that makes this a small-scale plume [Garvine, 1995]. Velocities near the mouth are strong (Figure $3 \mathrm{a}$ ) and like other smallscale plumes, the internal Froude number is order 1 at the inlet. This jetlike outflow is consistent with observations and numerical simulation results of the Merrimack estuary plume [Hetland and MacDonald, 2008; MacDonald et al., 2007].

[18] Next, we consider the vertical plume structure along two sections shown in Figure 2b: an along-axis line (AL) and a cross-axis line (CL). At the bay mouth, the surface salinity is $7.0 \mathrm{psu}$, and the plume depth is $1.1 \mathrm{~m}$ (Table 2). Plume surface salinities increase away from the mouth in all directions, and the plume thickness is less than $2 \mathrm{~m}$ everywhere (Figures $5 \mathrm{a}$ and $5 \mathrm{~b}$ ). The plume does not contact the bottom anywhere on the shelf.

\subsection{Response of Plume Structure to Wind Directions}

[19] Runs with moderate $(5 \mathrm{~m} / \mathrm{s})$ winds are added to each of the four compass points to examine the response to various wind directions. The plume structure and current fields 


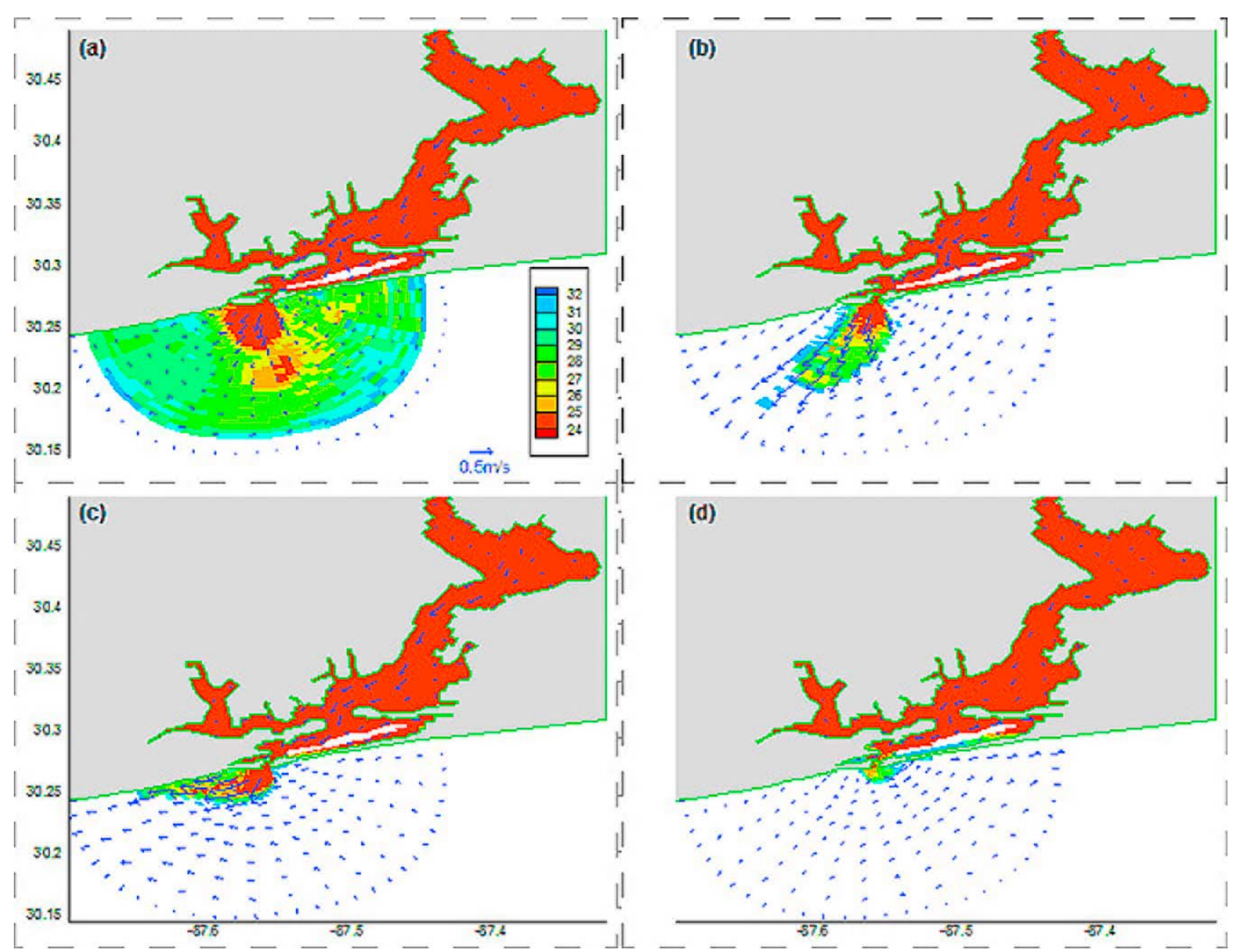

Figure 3. The surface plume and current structure after 8 days of simulation under (a) no wind, (b) northerly wind, (c) easterly wind, and (d) southerly wind.

Table 2. A Summary of the Plume Signature Under the Various Wind Forcing

\begin{tabular}{lcccccc}
\hline Experiment & Area $\left(\mathrm{km}^{2}\right)$ & Length $(\mathrm{km})$ & Width $(\mathrm{km})$ & Depth $(\mathrm{m})$ & Bay Mouth Salinity Value & Plume Center Salinity Value \\
\hline No_wind & 328.9 & 12.5 & 22.8 & 1.1 & 7.0 & 25.0 \\
N3 & 43.9 & 14.0 & 4.5 & 0.7 & 8.0 & 26.0 \\
N5 & 36.0 & 11.0 & 4.3 & 1.0 & 9.0 & 29.0 \\
N7 & 28.2 & 9.2 & 3.6 & 1.4 & 13.0 & 30.0 \\
N10 & 15.0 & 5.7 & 2.8 & 2.6 & 18.0 & 30.0 \\
N15 & 8.0 & 4.3 & 2.2 & 4.0 & 15.0 & 23.0 \\
E3 & 32.8 & 12.0 & 3.5 & 1.5 & 10.0 & 25.0 \\
E5 & 21.8 & 10.0 & 3.0 & 2.2 & 12.0 & 26.0 \\
E7 & 15.9 & 8.0 & 2.3 & 2.5 & 18.0 & 31.0 \\
E10 & 3.3 & 4.7 & 1.0 & 3.7 & 28.0 & 32.0 \\
E15 & 2.0 & 4.0 & 0.6 & 5.5 & 30.0 & 26.0 \\
S3 & 15.0 & 3.4 & 5.0 & 1.7 & 18.0 & 27.0 \\
S5 & 4.2 & 1.9 & 2.0 & 2.5 & 22.0 & N/A \\
S7 & N/A & N/A & N/A & N/A & N/A & N/A \\
S10 & N/A & N/A & N/A & N/A & N/A & 27.0 \\
S15 & N/A & N/A & N/A & N/A & 15.0 & 28.0 \\
W3 & 20.3 & 6.3 & 3.5 & 0.7 & 17.0 & 30.0 \\
W5 & 10.4 & 4.5 & 2.4 & 1.2 & 19.0 & 31.0 \\
W7 & 5.4 & 3.3 & 1.8 & 1.5 & 21.0 & 32.0 \\
W10 & 3.1 & 2.5 & 1.4 & 2.0 & 22.0 & \\
W15 & 1.7 & 1.9 & 1.0 & 3.5 & & \\
\hline
\end{tabular}



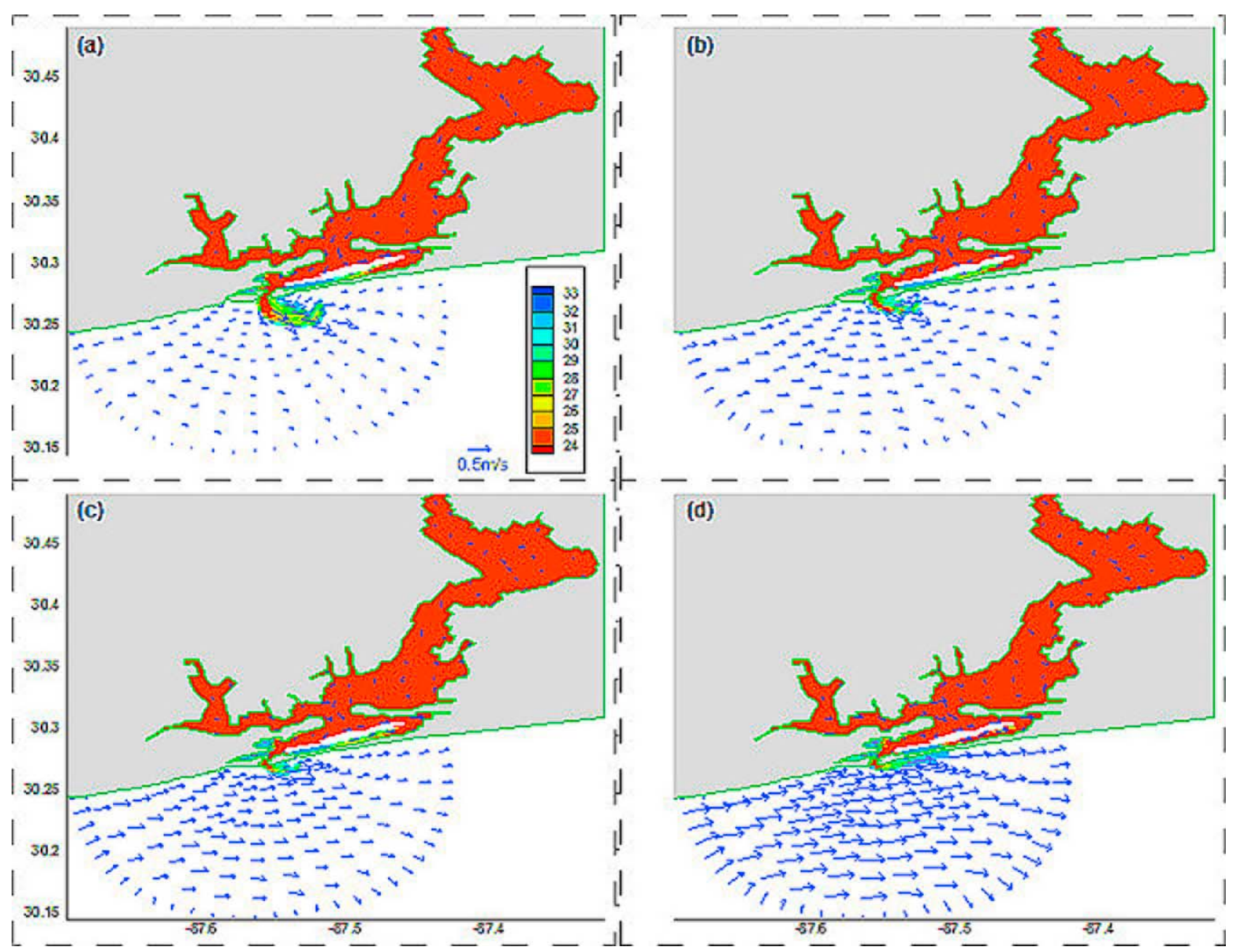

Figure 4. The westerly wind-induced surface plume and current structure after 8 days of simulation with wind magnitude of (a) $5 \mathrm{~m} / \mathrm{s}$, (b) $7 \mathrm{~m} / \mathrm{s}$, (c) $10 \mathrm{~m} / \mathrm{s}$, and (d) $15 \mathrm{~m} / \mathrm{s}$.

(Figures $3 \mathrm{~b}-3 \mathrm{~d}$ and $4 \mathrm{a}$ ) are different in each scenario. The plume is separated from the coast and flows toward the southwest when a northerly wind blows (Figure 3b). The plume turns to the right and hugs the western part of the southern coast under an easterly downwelling-favorable wind (Figure 3c). The plume area is smallest during a southerly wind, when buoyant waters are kept close to the bay mouth (Figure 3d). The plume is separated from the coast and turns to the southeast under a westerly upwellingfavorable wind (Figure 4a). Clearly, the horizontal distribution of the plume changes under these four different wind directions. These results also indicate that the surface plume area, length, and width are smaller for all wind conditions than without winds (Table 2). Furthermore, the large bulge is only present without winds. Among the wind-forced runs, the plume area and dimensions are largest for northerly and easterly winds and smallest for southerly and westerly winds (Table 2). Li et al. [2008] hypothesized that northerly winds induce a large plume area and visually tested this hypothesis by using satellite observations in their Gulf estuary plume study. Our simulations support their hypothesis in the application to PBE. Our results indicate northerly winds promote water transport toward the Gulf in the estuary and through the inlet, enhancing the freshwater flow from the PBE to the shelf. In contrast, it appears that southerly winds prevent most freshwater from leaving the estuary and lead to a small plume region.

[20] In the study area, easterly winds are downwelling favorable and westerly winds are upwelling favorable. In contrast to previous works showing that upwelling-favorable winds spread the surface plume and enlarged the plume size in the Amazon and Delaware respectively [Lentz, 1995; Whitney and Garvine, 2005], it was found that downwellingfavorable winds in the PBE could induce a larger plume surface area than upwelling-favorable winds. To understand the reasons for this different behavior, we will combine these plume distribution results with the bay-shelf water and salt flux in the next section.

[21] Next, we consider the vertical plume structure along the AL and CL sections. Easterly winds and northerly winds show freshwater reaching the bay mouth at 9-12 psu, while the westerly and southerly winds show higher surface salinities of 17-22 psu at the bay mouth (Table 2). These salinity differences in the buoyant waters exiting the mouth also support the previous discussion why westerly and southerly winds have a relatively small surface plume area compared to that of easterly and northerly winds. Plume depth at the mouth is similar to the no-wind case for westerly upwelling- 


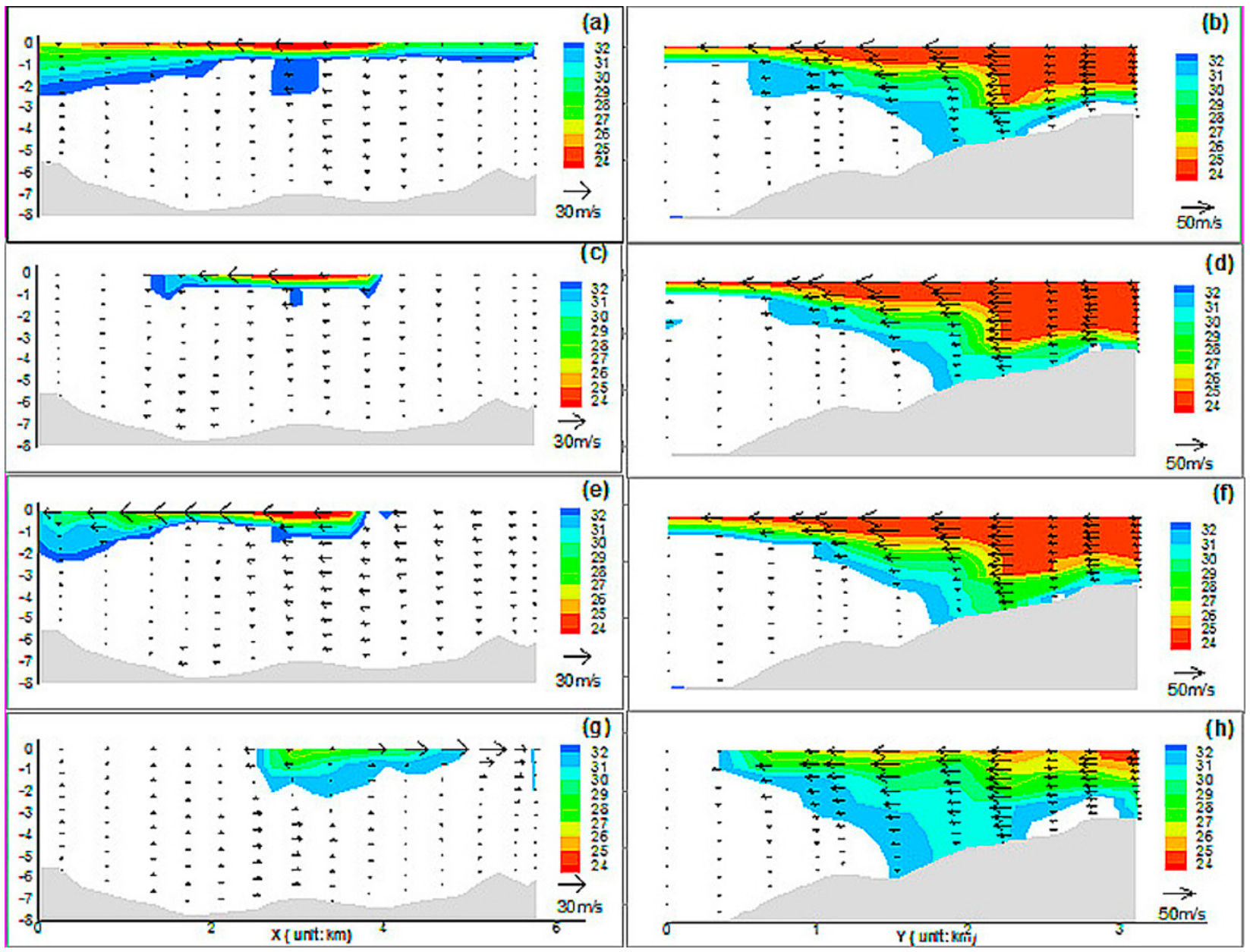

Figure 5. The $5 \mathrm{~m} / \mathrm{s}$ wind forcing induced vertical salinity profile and current field with wind direction of (a) no wind at the CL (X-Z direction), (b) no wind at the AL (Y-Z direction), (c) northerly wind at the CL, (d) northerly wind at the AL, (e) easterly wind at the CL, (f) easterly wind at the AL, (g) southerly wind $\mathrm{m} / \mathrm{s}$ at the CL, and (h) southerly wind at the AL.

favorable and northerly winds, but deeper for easterly downwelling-favorable and southerly winds (Figures 5, 6a, and $6 \mathrm{~b})$. On the shelf, the plume is deeper for easterly downwelling-favorable winds than for westerly upwellingfavorable winds. Thus, the simulation is consistent with previous studies of Whitney and Garvine [2005] and Fong and Geyer [2002] that report that an upwelling wind reduces the thickness of the plume. The current field is consistent with the vertical plume structure (Figures 5, 6a, and 6b). The variations in vertical plume structure under various wind directions are significant, but are not as dramatic as in the horizontal structure. The plume is dominant on the western shelf under easterly downwelling-favorable winds (Figure 5) and is limited to the eastern part of the water column during westerly upwelling-favorable winds (Figures 6a and 6b).

[22] The near bottom salinity value at the PBE mouth is nearly the same as the one that was marginally influenced by various weak or moderate wind conditions (e.g., $5 \mathrm{~m} / \mathrm{s}$ ). Overall, the plumes do not make bottom contact in the deepest water $(\sim 5 \mathrm{~m})$ under this wind effect. The phenomenon observed here is consistent with the previous discussion of García Berdeal et al. [2002] in the Columbia Estuary plume study, i.e., moderate wind forcing could strengthen surface mixing but has little influence on nearbottom salinity.

\subsection{Response of Plume Structure to Wind Speeds}

[23] The response of the plume shape to the wind magnitude is another interesting phenomenon that should be investigated. To address this issue, 16 additional experiments were conducted (Table 1) including 4 wind directions and wind speeds of $3 \mathrm{~m} / \mathrm{s}, 7 \mathrm{~m} / \mathrm{s}, 10 \mathrm{~m} / \mathrm{s}$ and $15 \mathrm{~m} / \mathrm{s}$. The plume size, (area, length, and width) are summarized in Table 2: the plume size was reduced as the wind speed increased from 3 to $15 \mathrm{~m} / \mathrm{s}$ due to enhanced surface mixing associated with increased wind speeds (Table 2). At the same time, surface salinity values at the river mouth and each individual plume center increased as the wind speed increased for a given wind direction (Figure 4 and Table 2); findings are consistent with the discussion of García Berdeal et al. [2002] in their study of the Columbia River Estuary plume. The westerly upwelling-favorable wind is approximately perpendicular to the major axis of the PBE and blows slightly offshore at the coast. As an example, this wind direction was chosen here in order to further examine the sensitivity of the PBE 3-D plume structure to wind 


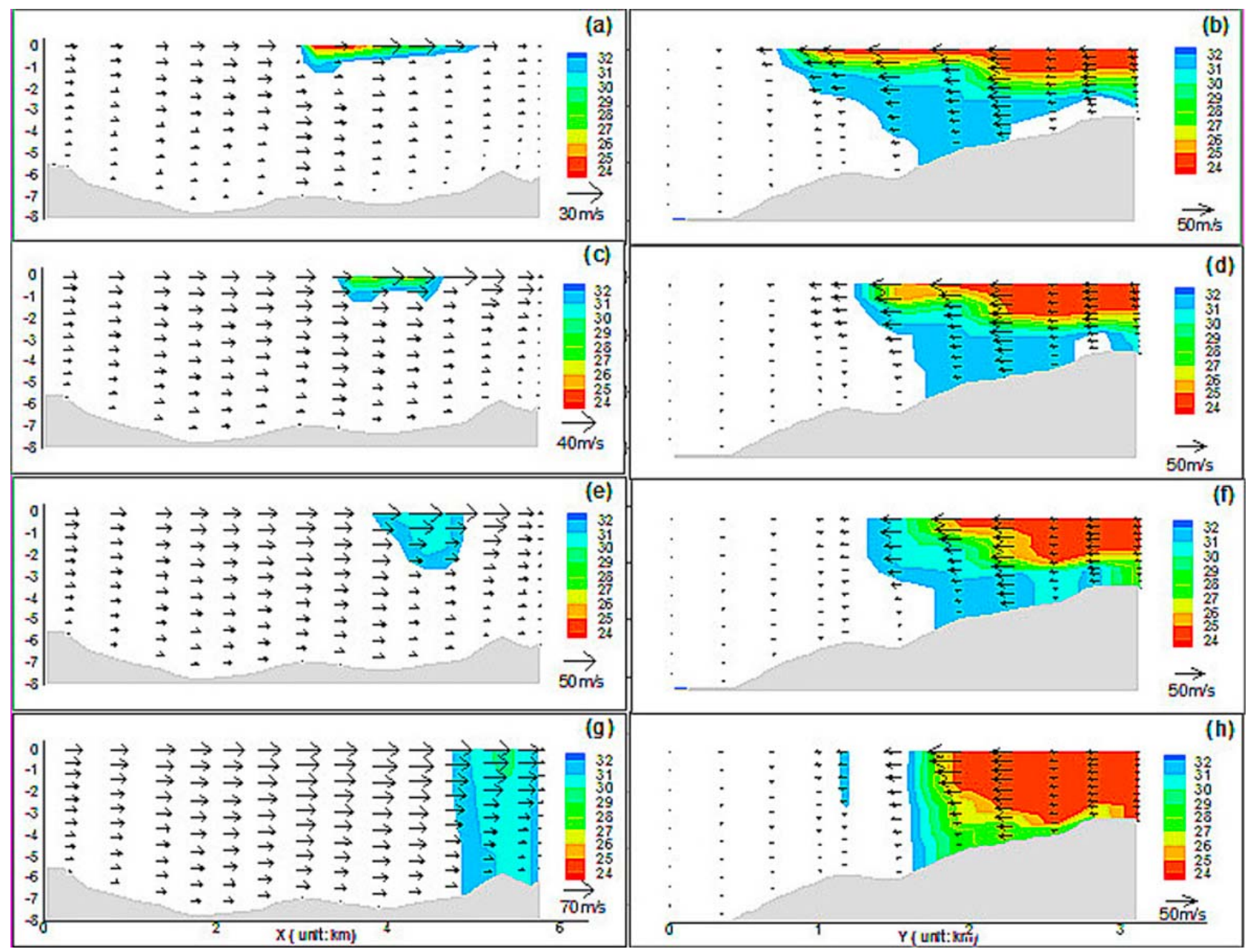

Figure 6. The westerly wind-induced vertical salinity profile and current field with wind magnitude of (a) $5 \mathrm{~m} / \mathrm{s}$ at the CL, (b) $5 \mathrm{~m} / \mathrm{s}$ at the AL, (c) $7 \mathrm{~m} / \mathrm{s}$ at the CL, (d) $7 \mathrm{~m} / \mathrm{s}$ at the AL, (e) $10 \mathrm{~m} / \mathrm{s}$ at the CL, (f) $10 \mathrm{~m} / \mathrm{s}$ at the $\mathrm{AL},(\mathrm{g}) 15 \mathrm{~m} / \mathrm{s}$ at the $\mathrm{CL}$, and (h) $15 \mathrm{~m} / \mathrm{s}$ at the AL.

magnitude. The westerly wind-induced plume hugs the east section of the southern coast as the wind magnitude increases, since wind forcing overcomes the relatively weak Coriolis force in controlling plume orientation (Figure 4). The results regarding the sensitivity of the PBE plume to wind forcing suggest that local wind forcing and its subsequent mixing fundamentally affect the surface plume structure in orientation, size, and salinity signature.

[24] For each wind direction, the plume deepens as the wind stress increases (Table 2). As shown in Figure 6, the vertical plume salinity distribution is more uniform at the bay mouth region, and the plume's length is much smaller; moreover, the depth of the plume increases slightly under the influence of a westerly wind, as shown in Figure 6, as the wind speed and the subsequent vertical mixing increase. The plume was continuously pushed to the east section of the bay mouth in keeping with the direct forcing of the westerly wind. The bottom salinity value changed slightly as the wind speed increased, and the bottom value was apparently influenced by the $15 \mathrm{~m} / \mathrm{s}$ wind speed. This is also consistent with the work of Georgiou and McCorquodale [2000] in the shallow Lake Pontchartrain estuary, another Gulf estuary. They found that only winds with speeds exceeding $11 \mathrm{~m} / \mathrm{s}$ could induce vertical mixing sufficient to overturn the water column. Based on the along-bay salinity plot and current field (Figure 6), salt water was continuously pushed back to the bay, increasing the salinity.

\section{Water and Salt Flux Simulation Under Wind Forcing}

[25] The above discussions shed light on salt transport variations with winds, but a more quantitative assessment of the salt flux is critical to establish a more complete understanding of plume dynamics and bay-shelf exchange. A quantitative assessment is discussed in this section. To our knowledge, the literature on plume dynamics research is not well developed in linking salt flux and water exchange. However, studies have been done to investigate the influence of the tide on salt flux and water exchange, such as the estuarine circulation and outflow plume for Chesapeake Bay by Guo and ValleLevinson [2007], an ideal estuary-coastal ocean volume exchange by Valle-Levinson et al. [1996], Gacic et al. [2004] for the Venice lagoon (Italy), and Stigebrandt [1983] in the study of the Baltic and Skagerrak bays (Sweden). Still, little research has been done on water exchange under a variety of wind forcing conditions, particularly in the plume region. A 
Table 3. The Water Flux and Salt Flux Under the Various Scenarios ${ }^{\mathrm{a}}$

\begin{tabular}{|c|c|c|c|c|c|c|c|c|c|c|}
\hline Experiment & Bottom Inflow & Bottom In-Salt & Surface Outflow & Surface Out-Salt & Ratio & Net Flow & Net Salt & West Flux & East Flux & Total \\
\hline No flow & 50.3 & 1858.2 & -14.1 & -52.0 & & 36.2 & 1806.2 & 3.1 & -42.6 & -3.3 \\
\hline No_wind & 31.7 & 1182.8 & -44.5 & -472.8 & 10.6 & -12.8 & 710.0 & -33.9 & -76.5 & -123.1 \\
\hline $\mathrm{N} 3^{-}$ & 35.5 & 1364.2 & -55.6 & -593.2 & 10.7 & -20.1 & 771.0 & -29.3 & -70.1 & -119.5 \\
\hline N5 & 32.1 & 1248.0 & -74.1 & -1127.1 & 15.2 & -42.0 & 120.9 & -22.3 & -51.8 & -116.1 \\
\hline N7 & 29.6 & 1138.9 & -103.9 & -2116.3 & 20.4 & -74.3 & -977.4 & -12.1 & -25.0 & -111.4 \\
\hline N10 & 31.3 & 1153.1 & -173.0 & -3886.9 & 22.5 & -141.7 & -2733.8 & 12.8 & 27.6 & -101.3 \\
\hline N15 & 33.1 & 1260.3 & -332.5 & -7337.9 & 22.1 & -299.4 & -6077.6 & 83.0 & 134.1 & -82.3 \\
\hline E3 & 36.1 & 1360.0 & -47.7 & -469.4 & 9.8 & -11.6 & 890.6 & -59.8 & -50.0 & -121.4 \\
\hline E5 & 37.0 & 1383.5 & -54.9 & -740.6 & 13.5 & -17.9 & 642.9 & -90.0 & -12.7 & -120.6 \\
\hline E7 & 34.2 & 1274.7 & -56.5 & -994.1 & 17.6 & -22.3 & 280.6 & -138.5 & 40.9 & -119.9 \\
\hline E10 & 25.6 & 992.7 & -48.5 & -935.1 & 19.3 & -22.9 & 57.6 & -228.8 & 132.5 & -119.2 \\
\hline E15 & 23.7 & 989.9 & -34.5 & -404.9 & 11.7 & -10.8 & 585.0 & -394.3 & 275.2 & -129.9 \\
\hline S3 & 23.8 & 885.8 & -33.7 & -561.3 & 16.7 & -9.9 & 324.5 & -34.6 & -76.0 & -120.5 \\
\hline S5 & 17.6 & 646.1 & -10.3 & 20.0 & & 7.3 & 666.1 & -43.4 & -86.0 & -122.2 \\
\hline S7 & 40.5 & 1564.3 & 0.0 & 0.0 & & 40.5 & 1564.3 & -57.9 & -108.8 & -126.2 \\
\hline $\mathrm{S} 10$ & 112.2 & 3880.7 & -0.1 & 0.1 & & 112.1 & 3880.8 & -96.5 & -150.2 & -134.6 \\
\hline S15 & 268.9 & 9109.2 & 0.1 & 0.3 & & 269.0 & 9109.5 & -194.2 & -226.1 & -151.3 \\
\hline W3 & 25.2 & 849.8 & -41.5 & -624.6 & 15.1 & -16.3 & 225.2 & -13.6 & -89.6 & -119.5 \\
\hline W5 & 21.3 & 790.8 & -44.4 & -890.2 & 20.0 & -23.1 & -99.4 & 19.6 & -114.4 & -117.9 \\
\hline W7 & 22.3 & 796.7 & -52.1 & -1113.1 & 21.4 & -29.8 & -316.4 & 76.8 & -162.7 & -115.7 \\
\hline W10 & 22.9 & 808.5 & -66.6 & -1408.8 & 21.2 & -43.7 & -600.3 & 150.5 & -219.4 & -112.6 \\
\hline W15 & 21.1 & 783.2 & -99.1 & -2003.1 & 20.2 & -78.0 & -1219.9 & 341.4 & -365.0 & -101.6 \\
\hline
\end{tabular}

${ }^{a}$ Unit is cms. The bottom inflow or in-salt is the total water or salt flux for the offshore direction and vice versa for the surface outflow and surface outsalt. Ratio is from the surface out-salt to surface outflow. Net flow and net salt are calculated at the Perdido bay mouth. West flux is the water flux calculated near the western channel part. East flux is calculated near the eastern channel part. Total is a total of net flow at the bay mouth, western channel and eastern channel.

question raised in section 3 is why westerly upwellingfavorable winds tend to decrease the surface PBE plume size, while upwelling-favorable winds increase the plume area in the Delaware estuary [Whitney and Garvine, 2005]? To answer it, salt flux and water exchange calculations are made for the 22 separate but similar scenarios already discussed (Table 1).

[26] Results show the water and salt fluxes during the plume simulation period for each scenario (Table 3). Without wind forcing and river inflow, the surface water flux at the Perdido Bay mouth is $14 \mathrm{cms}$; this increases to $45 \mathrm{cms}$ with the river inflow included. The total of the net volume fluxes through the bay mouth, the east inlet to Pensacola, and the west inlet to Dauphin Island is very close to the combined river inputs from the Perdido River and Eleven Mile Creek ( $120 \mathrm{~m}^{3} / \mathrm{s}$ total) for the no wind scenario (Table 3). From Table 3, it is obvious that water fluxes are very sensitive to the changing wind direction. The detailed relationship and water flux variation between these three inlets are beyond the scope of this study, however it could be seen that this relationship does have a significant impact on the salt and water fluxes directly from the bay mouth to the Gulf. For water exchange, the simulation reveals that the surface outflow varies more with wind forcing than the bottom inflow. Consequently, variations in the net water exchange are greatly influenced by the surface outflow and little by the bottom inflow. Under a northerly wind (blowing outwards along the Perdido inlet) the surface outflow is many times stronger than the other wind directions (Table 3 ). The water exchange grows larger with increasing northerly wind speed. This increased outflow partially explains why northerly winds induce a relatively large surface plume compared to other wind directions. In contrast, southerly winds shut off the outflow and increase inflow through the bay mouth.

[27] Surface outflow increases for westerly winds. The outflow increases for easterly winds from 3 to $7 \mathrm{~m} / \mathrm{s}$ and decreases for higher wind speeds. The bottom inflow also decreases at high easterly wind speeds. The mixed response may be due to the variations in transport through the east and west passes and across-shelf circulation typical of downwelling-favorable winds (onshore at the surface and offshore at depth) that counters the no wind flow pattern. Outflow is greater for easterly downwelling-favorable winds than for westerly upwelling-favorable winds for wind speeds up to $7 \mathrm{~m} / \mathrm{s}$. This outflow difference explains the issue raised in the previous section of why the plume area under downwelling-favorable conditions is larger than for upwelling-favorable conditions (a $5 \mathrm{~m} / \mathrm{s}$ wind speed), despite the tendency of upwelling-favorable winds to spread plume waters offshore. At higher wind speeds, however, outflows are higher for upwelling-favorable winds, and the plume area is similar to that for downwelling-favorable winds (Tables 2 and 3 ).

[28] Although water flux could partially answer the question raised from plume dynamics studies, why does increasing wind speed promote water flux but inhibit plume formation, particularly the surface plume size? To address this plume dynamics issue, we will discuss salt flux. For the surface salt flux to the coastal ocean, the trend with wind speed for each wind direction is very similar to that of the corresponding water flux. The ratio of the salt flux and water flux for the outflow increases with wind speed (Table 3 ). This ratio can be interpreted as the average salinity of the outflow. Thus, even though the outflow increases with wind speed, the associated salinities are higher. The higher mouth salinities reduce the surface plume structure (Tables 2 and 3 and Figure 6).

[29] Overall, the outflow under a no winds condition is not as strong as that for a northerly wind, but the surface salinity value is lower. This salinity difference indicates winds increase vertical mixing within the bay. The larger fresher water transport in the no wind case creates a more 


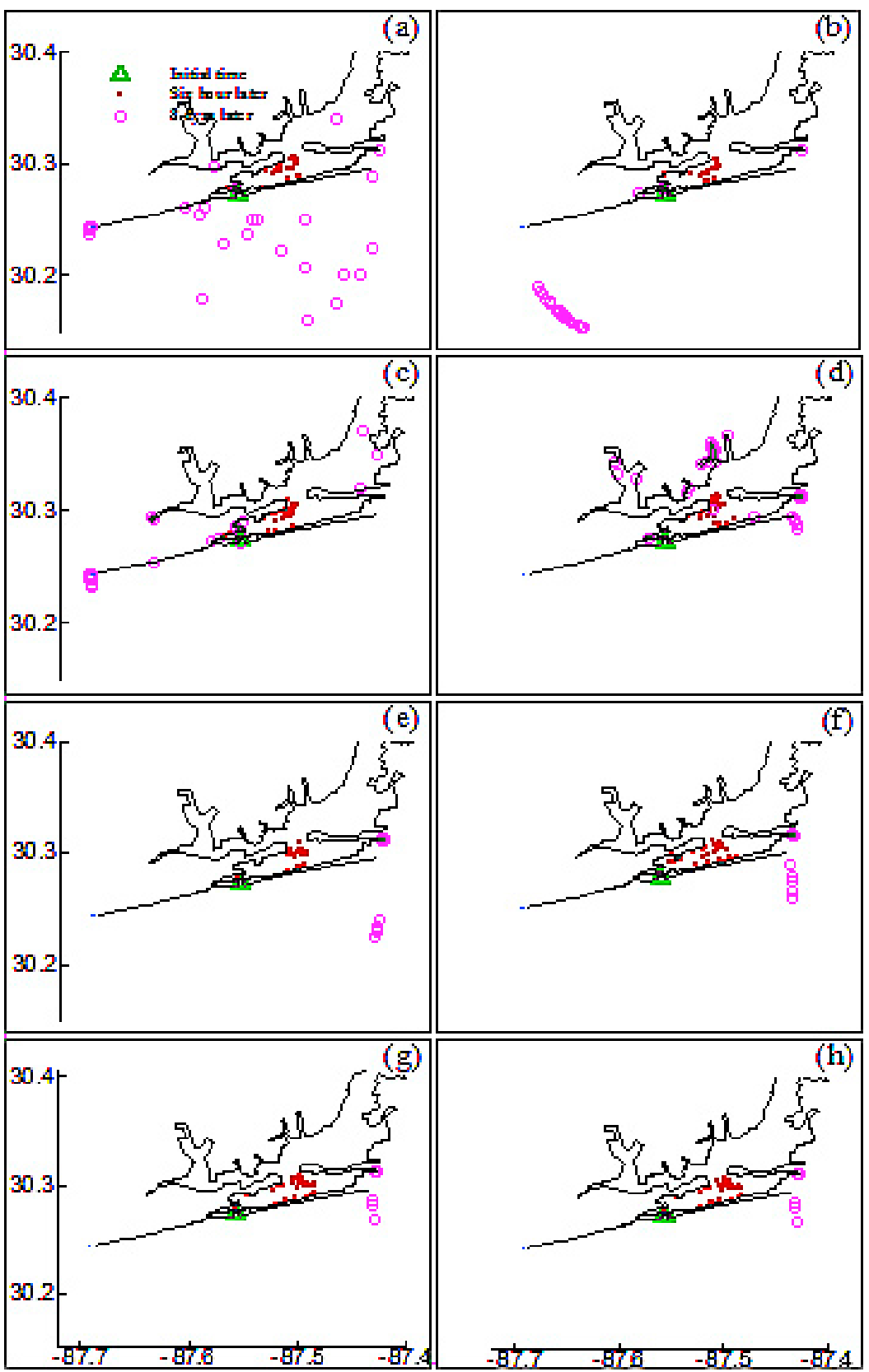

Figure 7. The horizontal distribution of the particle after 8 days of simulation under (a) no wind, (b) northerly wind, (c) easterly wind, (d) southerly wind, (e) westerly wind with $3 \mathrm{~m} / \mathrm{s}$, (f) westerly wind with $5 \mathrm{~m} / \mathrm{s}$; (g) westerly wind with $10 \mathrm{~m} / \mathrm{s}$, and (h) westerly wind with $15 \mathrm{~m} / \mathrm{s}$.

prominent surface plume than in the northerly wind and other forced wind cases. Even though northerly winds increase outflow to the coastal ocean (Table 3), the surface salinity value is also higher due to the increasing windinduced mixing inside the bay and on the shelf (Table 3). Thus, the surface plume signature and plume extent is reduced relative to no wind conditions.

\section{Lagrangian Simulation of Estuary Dynamics and Water Exchange}

[30] Additional insight concerning plume simulation performance and the nature of the water exchange can be gained by looking at particle transport. Particle transport simulations have been conducted in previous plume dynamics studies, such as Whitney and Garvine [2006] and Banas et al. [2009]. In this section, a group of 30 particle trajectories starting in the inlet between the bay and shelf before flood tide are shown in Figure 7 for different vertical locations (spanning 0.25 to $4.57 \mathrm{~m}$ deep). The runs including particle transport have the same model settings as the runs for plume distributions and water exchange simulations (Table 1). For a view of net advection and dispersion, the particle locations after 8 days are shown in Figure 7, presented in a plane view. These scenes can be compared with the plume distribution under the various wind forcing 


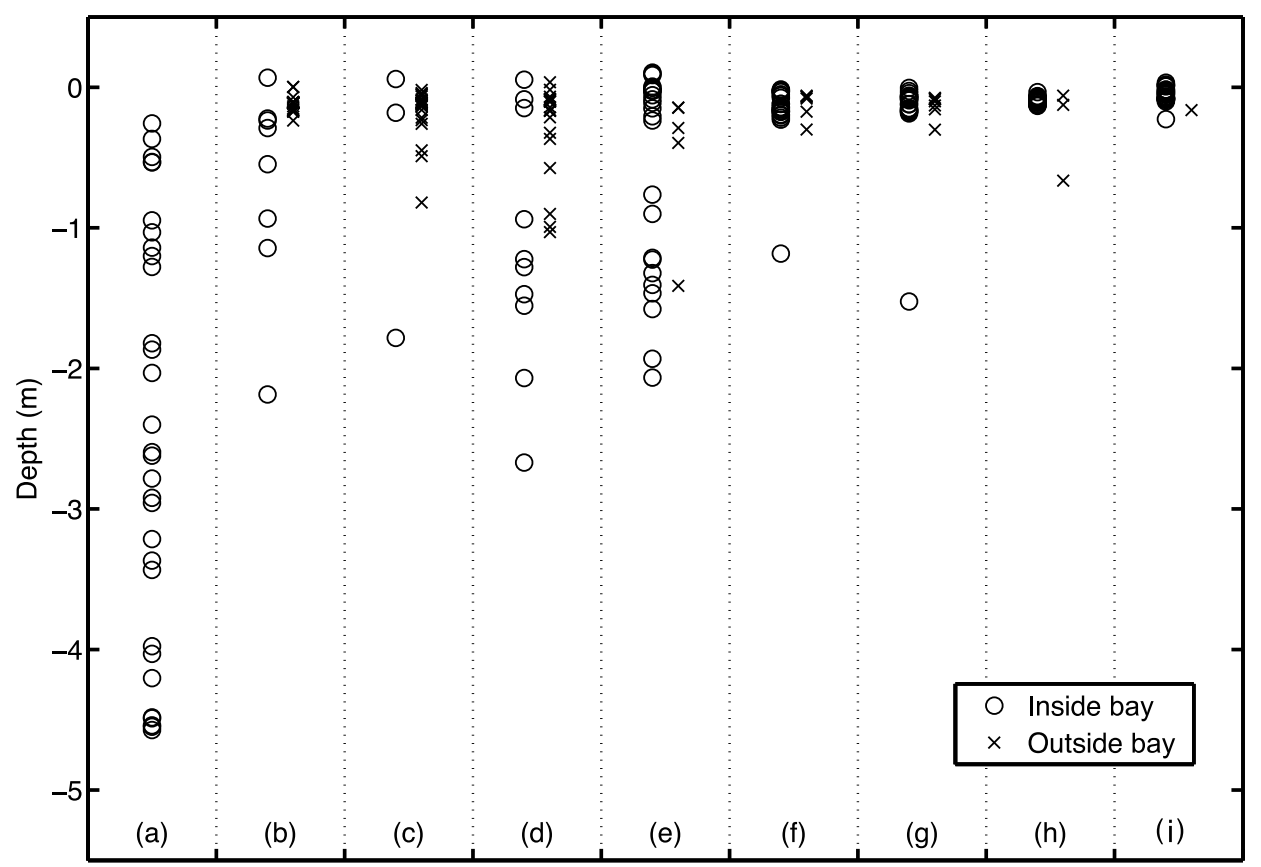

Figure 8. (a) Initial conditions. The vertical distribution of the particle after 8 days of simulation under (b) no wind, (c) northerly wind, (d) easterly wind, (e) southerly wind, (f) westerly wind with $3 \mathrm{~m} / \mathrm{s}$, (g) westerly wind with $5 \mathrm{~m} / \mathrm{s}$, (h) westerly wind with $10 \mathrm{~m} / \mathrm{s}$, and (i) westerly wind with $15 \mathrm{~m} / \mathrm{s}$.

scenarios. Initially all particles moved eastward inside the bay under the influence of the flood tide. After an 8 day simulation, some have been advected farther into the bay, while others have been advected to the shelf (Figure 7). These drifter data highlight the wind's influence on surface plume dynamics and bottom gravitational circulation. With no wind forcing, the particles are predominantly advected outside of the bay; the eight that remain were initialized deeper and were advected under the influence of the bottom gravity circulation. Under the influence of an easterly downwelling-favorable wind or a northerly wind, the particle distribution shows that water moves to the coastal ocean with only 3 staying in the bay in the case of northerly winds and 10 in the easterly wind scenario. It should be mentioned that the particles were pushed back due to a tidal flood, following the initial release (Figure 7). So an easterly wind moves particles to the western part of the bay, which prevents them from flowing back into the coastal ocean. The westerly upwelling favorable wind and southerly wind cause most particles to remain inside the bay (Figure 7). Particle depths (Figure 8) indicate that easterly and southerly winds and no winds cause the particles to stay in the deep water (at around $2 \mathrm{~m}$ ), while the upwelling wind moved all particles to shallower regions (less than $1 \mathrm{~m}$ ). With regard to the influence of wind speed, the particle trajectories differ significantly in various cases (Figure 7). More particles will be pushed back to the bay, and less will reach the coastal ocean as wind speeds increase. From Figure 8, particles become limited to the surface layer with increasing wind forcing; an increased wind could influence the bottom water and cause bottom particles to reach the surface.

[31] Particle trajectories shown in Figures 7 and 8 represent the advection of individual water parcels under the various forcing conditions. During the entire time period shown, the wind plays an important role in particle distribution, which directly relates to the surface plume structure discussed above. For example, the surface plume has a relatively large size (Figure 3a) under a no wind forcing scenario and more particles move to the coastal ocean, floating far from the inlet. Particles are found to make this bay-to-shelf connection under all conditions except for the strongest wind cases, which is consistent with the findings in the Columbia Estuary plume studies [Banas et al., 2009]. Thus, plume dynamics introduce heterogeneity into the fate of particles and water exchange.

\section{Discussion and Conclusion}

[32] Several questions were raised at the beginning of this article concerning how wind forcing affects bay water as it encounters the Gulf and how plume distribution, fluxes, and particle transport change with changing wind conditions. To answer these questions, this paper discussed the effects of wind forcing on plume structure, water exchange, salt flux, and particle transport for the PBE. Although the plume dynamics discussed here have not been compared to actual observations, such as can be seen in satellite imagery, they were compared to results from previous plume dynamics studies in the estuary and coastal ocean. Based on these comparisons, it can be concluded that winds are very critical to plume formation and its signature in this Gulf estuary. The plume's response to the effects of wind forcing are summarized below.

[33] Although the low tidal energy should also be important for the Gulf bay system, the relatively shallow Gulf bay was confirmed to be significantly influenced by 
winds. Without wind forcing, the plume shows a jet structure and has a relatively large size that spreads along the coast in both directions and offshore. The jetlike plume is related to the narrow width of the bay mouth that is much smaller than the internal deformation radius; making it a small-scale plume [Garvine, 1995]. The plume is similar to the plume pattern discovered in the Marrick estuary plume [Hetland and MacDonald, 2008; MacDonald et al., 2007]. The 3-D plume structure is then dramatically different with the inclusion of wind forcing. This modeling study demonstrates that the surface plume range is reduced under all wind conditions for $5 \mathrm{~m} / \mathrm{s}$ wind speeds or greater. The width and area are always smaller than that of no wind forcing. Plume depth at the mouth is similar to the no wind case for westerly upwelling-favorable and northerly winds, but deeper for easterly downwelling-favorable and southerly winds. In addition, plume orientation and range are obviously different for different directions. The plume is farthest offshore for northerly winds and confined closest to the coast and smallest for southerly winds. The plume extends westward (downshelf) for easterly downwelling-favorable winds and is deflected offshore and eastward for westerly upwelling-favorable winds. For all directions, increasing wind speeds decrease plume area partially due to more energetic vertical mixing in the bay and on the shelf.

[34] Water fluxes and salt fluxes through the bay mouth were calculated and then compared under the conditions of variable wind forcing. The results indicate that wind forcing is acting significantly on the water exchanges and subsequent salt flux. Compared to the previous work of Gacic et al. [2004] in their study of the Venice Lagoon that show the importance of the tides in inlet water flux, our findings support the important relationship of winds to water exchange and salt flux, which was not considered in previous work [e.g., Guo and Valle-Levinson, 2007; ValleLevinson et al., 1996; Stigebrandt, 1983]. This study fills a gap in existing research connecting plume dynamics, salt flux, and water exchange. At a given wind speed, different wind directions induce significantly different outflow trends that are critical to plume dynamics. Northerly winds generate more outflow and a larger plume size than any other wind direction. Southerly winds arrest the outflow; consequently, there is little or no surface plume under this wind direction. Westerly upwelling-favorable winds increase outflow for all wind speeds, but this outflow is less than for downwelling-favorable winds for increased speeds, particularly after $7 \mathrm{~m} / \mathrm{s}$. This outflow relationship helps explain why the plume area is larger for downwelling-favorable conditions at $5 \mathrm{~m} / \mathrm{s}$ wind speed in contrast to the expectation from previous studies that spreading during upwellingfavorable conditions creates a larger plume. The salt flux follows the same trends as water flux, but the ratio of the fluxes increases with wind speed, indicating the outflow salinity is larger for higher winds (due to mixing in the bay). The higher outflow salinities leads to a smaller salinity signature throughout the plume and is an important factor causing the plume area to decrease with increasing wind speeds. A key conclusion is that bay-shelf water and salt flux through the bay mouth is crucial to the plume dynamics for this Gulf bay system.

[35] The particle transport experiments discussed here highlight the importance of winds to the Gulf estuaries pollutant transport and plume dynamics. For the cases of easterly wind and northerly winds or no wind, particles are most likely pushed outside, while for the case of westerly upwelling or southerly winds, most of the particles will be kept inside. These models of particle transport are consistent with the previous conclusions that wind itself has important effects on material exchanges [Samelson and Wiggins, 2006; Banas et al., 2009].

[36] It should be mentioned that there are some limitations to this work, such as only idealized experiments were conducted, and the subsequent results only offer insights into a better understanding of the dynamic processes of the plume. The lack of a comparison of the plume dynamics results with remote sensing imagery and the effects of river discharge on the dynamics of the plume were not included in the paper. Likewise, the ideal plume dynamics and the Lagrangian modeling experiments also have some differences with real scenarios. However, these ideal experiments are important steps for future plume dynamics and Lagrangian investigations with real scenarios. For the first time, the physical processes that govern the interaction between the bay and coastal ocean are described for Perdido Bay. The results show the significant importance of winds to the relatively low tide energy and shallow bay system and its plume in the adjacent coastal ocean. It is clear that conditions in the bay and in the inlet strongly influence fluxes and plume structure. These models should also be the pilot work for other estuaries in the Gulf and shallow bay systems in other areas.

[37] Acknowledgments. Michael M. Whitney brought the idea to link water flux with plume dynamics to initiate this work. No funding supported this work, as all modeling activities were carried out at the Cooperative Institute for Limnology and Ecosystems Research, University of Michigan. We acknowledge the support of NOAA's Great Lakes Environmental Research Environmental Laboratory (GLERL) for the consistent support and the encouragement from David Schwab. The authors appreciate the detailed editorial suggestions made by two anonymous reviewers. This is GLERL contribution 1592 .

\section{References}

Banas, N., P. MacCready, and B. Hickey (2009), The Columbia River plume as cross-shelf exporter and along-coast barrier, Cont. Shelf Res., 29, 292-301, doi:10.1016/j.csr.2008.03.011.

Beardsley, R. C., R. Limeburner, H. Yu, and G. A. Cannon (1985), Discharge of the Changjiang (Yangtze River) into the East China Sea, Cont. Shelf Res., 4, 57-76, doi:10.1016/0278-4343(85)90022-6.

Blumberg, A., and G. Mellor (1987), A description of a three-dimensional coastal ocean circulation model, in Three-Dimensional Coastal Ocean Models, Coastal Estuarine Sci., vol. 4, edited by N. S. Heaps, pp. 1-16, AGU, Washington, D. C.

Chao, S. (1988), River-forced estuarine plumes, J. Phys. Oceanogr., 18 72-88, doi:10.1175/1520-0485(1988)018<0072:RFEP $>2.0 . C O ; 2$.

Chao, S., and W. Boicourt (1986), Onset of estuarine plumes, J. Phys. Oceanogr., 16, 2137-2149, doi:10.1175/1520-0485(1986)016<2137: OOEP $>2.0 . \mathrm{CO} ; 2$.

Dunsbergen, D., and G. Stalling (1993), The combination of a random walk method and a hydrodynamic model for the simulation of dispersion of dissolved matter in water, in Water Pollution II: Modelling, Measuring and Prediction, pp. 235-242, Comput. Mech., Boston, Mass.

Fong, D., and W. Geyer (2002), The alongshore transport of freshwater in a surface-trapped river plume, J. Phys. Oceanogr., 32, 957-972, doi:10.1175/1520-0485(2002)032<0957:TATOFI $>2.0 . C O ; 2$.

Gacic, M., I. Mancero Mosquera, V. Kovacevic, A. Mazzoldi, V. Cardin, F. Arena, and G. Gelsi (2004), Temporal variations of water flow between the Venetian lagoon and the open sea, J. Mar. Syst., 51(1-4), 33-47, doi:10.1016/j.jmarsys.2004.05.025. 
Galperin, B., L. Kantha, S. Hassid, and A. Rosati (1988), A quasi-equilibrium turbulent energy model for geophysical flows, J. Atmos. Sci., 45(1), 55-62, doi:10.1175/1520-0469(1988)045<0055:AQETEM>2.0.CO;2.

García Berdeal, I., B. Hickey, and M. Kawase (2002), Influence of wind stress and ambient flow on a high discharge river plume, J. Geophys. Res., 107(C9), 3130, doi:10.1029/2001JC000932

Garvine, R. (1987), Estuary plumes and fronts in shelf waters: A layer model, J. Phys. Oceanogr., 17, 1877-1896, doi:10.1175/1520-0485(1987) $017<1877$ :EPAFIS $>2.0 . \mathrm{CO} ; 2$.

Garvine, R. (1995), A dynamical system for classifying buoyant coastal discharge, Cont. Shelf Res., 15, 1585-1596, doi:10.1016/0278-4343(94) 00065-U.

Garvine, R. (1999), Penetration of buoyant coastal discharge onto the continental shelf: A numerical model experiment, J. Phys. Oceanogr., 29, 1892-1909, doi:10.1175/1520-0485(1999)029<1892:POBCDO >2.0. $\mathrm{CO} ; 2$.

Garvine, R. (2001), The impact of model configuration in studies of buoyant coastal discharge, J. Mar. Res., 59(2), 193-225, doi:10.1357/ 002224001762882637.

Georgiou, I., and A. McCorquodale (2000), Salinity stratification from a navigation canal into a shallow lake, in Stratified Flows, edited by G. A. Laurence, R. Pieters, and N. Yonemitsu, pp. 859-864, Int. Assoc. for Hydraul. Res., Univ. of B. C., Vancouver, B. C., Canada.

Geyer, W. (1997), Influence of wind on dynamics and flushing of shallow estuaries, Estuarine Coastal Shelf Sci., 44(6), 713-722, doi:10.1006/ ecss.1996.0140.

Guo, X., and A. Valle-Levinson (2007), Tidal effects on estuarine circulation and outflow plume in the Chesapeake Bay, Cont. Shelf Res., 27, 20-42, doi:10.1016/j.csr.2006.08.009.

Hamrick, J. (1992), A three-dimensional environmental fluid dynamics computer code: Theoretical and computational aspects, Tech. Rep. 317 , Va. Inst. of Mar. Sci., Coll. of William and Mary, Williamsburg.

Hetland, R. D., and D. G. MacDonald (2008), Spreading in the near-field Merrimack River plume, Ocean Modell., 21, 12-21, doi:10.1016/j.ocemod. 2007.11.001.

Hickey, B. M., L. J. Pietrafesa, D. A. Jay, and W. C. Boicourt (1998), The Columbia River plume study: Substantial variability in the velocity and salinity field, J. Geophys. Res., 103(C5), 10,339-10,368, doi:10.1029/ 97JC03290.

Kourafalou, V., T. Lee, L. Oey, and J. Wang (1996a), The fate of river discharge on the continental shelf: 2 . Transport of coastal low-salinity waters under realistic wind and tidal forcing, J. Geophys. Res., 101(C2), 3435-3455, doi:10.1029/95JC03025.

Kourafalou, V., L. Oey, J. Wang, and T. Lee (1996b), The fate of river discharge on the continental shelf: 1 . Modeling the river plume and the inner shelf coastal current, J. Geophys. Res., 101(C2), 3415-3434, doi:10.1029/ 95JC03024.

Lentz, S. (1995), The Amazon River Plume during AMASSEDS: Subtidal current variability and the importance of wind forcing, J. Geophys. Res., 100(C2), 2377-2390, doi:10.1029/94JC00343.

Li, C., N. Walker, A. Hou, I. Georgiou, H. Roberts, E. Laws, J. McCorquodale, E. Weeks, X. Li, and J. Crochet (2008), Circular plumes in Lake Pontchartrain estuary under wind straining, Estuarine Coastal Shelf Sci., 80(1), 161-172, doi:10.1016/j.ecss.2008.07.020.

MacDonald, D. G., L. Goodman, and R. D. Hetland (2007), Turbulent dissipation in a near-field river plume: A comparison of control volume and microstructure observations with a numerical model, J. Geophys. Res., 112, C07026, doi:10.1029/2006JC004075.

Marques, W., E. Fernandes, I. Monteiro, and O. Möller (2009), Numerical modeling of the Patos Lagoon coastal plume, Brazil, Cont. Shelf Res., 29, 556-571, doi:10.1016/j.csr.2008.09.022.
Mellor, G., and T. Yamada (1982), Development of a turbulence closure model for geophysical fluid problems, Rev. Geophys., 20(4), 851-875, doi:10.1029/RG020i004p00851.

Naudin, J., G. Cauwet, M. Chretiennot-Dinet, B. Deniaux, J. Devenon, and H. Pauc (1997), River discharge and wind influence upon particulate transfer at the land-ocean interaction: Case study of the Rhône river plume, Estuarine Coastal Shelf Sci., 45(3), 303-316, doi:10.1006/ ecss. 1996.0190

O'Donnell, J. (1990), The formation and fate of a river plume: A numerical model, J. Phys. Oceanogr., 20, 551-569, doi:10.1175/1520-0485(1990) $020<0551$ :TFAFOA $>2.0$. CO; 2 .

Samelson, R., and S. Wiggins (2006), Lagrangian Transport in Geophysical Jets and Waves: The Dynamical Systems Approach, Springer, New York.

Smagorinsky, J. (1963), General circulation experiments with the primitive equations: 1. The basic experiment, Mon. Weather Rev., 91, 99-164, doi:10.1175/1520-0493(1963)091<0099:GCEWTP>2.3.CO;2.

Smolarkiewicz, P. K. (1983), A simple positive definite advection transport scheme with small implicit diffusion, Mon. Weather Rev., 111, 479-486, doi:10.1175/1520-0493(1983)111<0479:ASPDAS>2.0.CO;2.

Stigebrandt, A. (1983), A model for the exchange of water and salt between the Baltic and the Skagerrak, J. Phys. Oceanogr., 13, 411-427, doi:10.1175/1520-0485(1983)013<0411:AMFTEO>2.0.CO;2.

Stumpf, R., G. Gelfenbaum, and J. Pennock (1993), Wind and tidal forcing of a buoyant plume, Mobile Bay, Alabama, Cont. Shelf Res., 13, 1281-1301, doi:10.1016/0278-4343(93)90053-Z.

Takano, K. (1955), A complementary note on the diffusion of the seaward flowing off the mouth, J. Oceanogr. Soc. Jpn., 11, 147-149.

Valle-Levinson, A., and J. Blanco (2004), Observations of wind influence on exchange flows in a strait of the Chilean Inland Sea, J. Mar. Res., 62(5), 720-740, doi:10.1357/0022240042387565.

Valle-Levinson, A., J. Klinck, and G. Wheless (1996), Inflows/outflows at the transition between a coastal plain estuary and the coastal ocean, Cont. Shelf Res., 16(14), 1819-1847, doi:10.1016/0278-4343(96)00016-7.

Whitney, M., and R. Garvine (2005), Wind influence on a coastal buoyant outflow, J. Geophys. Res., 110, C03014, doi:10.1029/2003JC002261.

Whitney, M., and R. Garvine (2006), Simulating the Delaware Bay buoyant outflow: Comparison with observations, J. Phys. Oceanogr., 36, 3-21, doi:10.1175/JPO2805.1.

Wiseman, W., N. Rabalais, R. Turner, S. Dinnel, and A. MacNaughton (1997), Seasonal and interannual variability within the Louisiana coasta current: Stratification and hypoxia, J. Mar. Syst., 12(1-4), 237-248, doi:10.1016/S0924-7963(96)00100-5

Xia, M., L. Xie, and L. Pietrafesa (2007), Modeling of the Cape Fear River Estuary plume, Estuaries Coasts, 30(4), 698-709.

Xia, M., P. Craig, C. Wallen, A. Stoddard, J. Mandrup-Poulsen, M. Peng, B. Schaeffer, and Z. Liu (2011), Numerical simulation of salinity and dissolved oxygen at Perdido Bay and adjacent coastal ocean, J. Coastal Res., 27(1), 73-86, doi:10.2112/JCOASTRES-D-09-00044.1.

Zhang, Q., G. Janowitz, and L. Pietrafesa (1987), The interaction of estuarine and shelf waters: A model and applications, J. Phys. Oceanogr. 17, 455-469, doi:10.1175/1520-0485(1987)017<0455:TIOEAS $>2.0$. $\mathrm{CO} ; 2$.

L. J. Pietrafesa, Center for Marine and Wetland Studies, Coastal Carolina University, PO Box 261954, Conway, SC 29528, USA

M. M. Whitney, Department of Marine Sciences, University of Connecticut, 1080 Shennecossett Rd., Groton, CT 06340, USA.

M. Xia, NOAA Living Marine Resources Cooperative Science Center, Department of Natural Sciences, University of Maryland Eastern Shore, Princess Anne, MD 21853, USA. (mxia@umes.edu)

L. Xie, Department of Marine, Earth, and Atmospheric Sciences, North Carolina State University, PO Box 8208, Raleigh, NC 27695-8208, USA. 